\author{
Liudmila Kirikova \\ Lithuanian University of Health Sciences, Lithuania \\ Irmantas Ramanauskas \\ Lithuanian University of Health Sciences, Lithuania \\ Edita Latvelienè \\ Lithuanian University of Health Sciences, Lithuania \\ Sigita Stankevičienè \\ A. Stulginskis University, Lithuania
Dalia Kačergiené
Kaunas University of Technologies, Lithuania
}

\title{
PECULIARITIES OF FOREIGN LANGUAGE LEARNING AT LUHS, KTU, AND ASU: THE STUDENTS' ATTITUDE
}

Summary. An increasing significance of science, a rapidly growing stream of information, and new cultural and business relationships with foreign countries are but a few factors that affect the education and training of specialists; therefore, providing practical ability to communicate in several foreign languages is one of the major components of today's education. Continuous updating of specialist knowledge, access to the most recent literature in foreign languages, possibilities for participation in various international conferences and joint projects with foreign partners, and the associated need for foreign languages highlight the relevance of the education and training of specialists who would not limit their activity to work in a concrete sphere, but rather - on the basis of the concept of life-long learning - would be able to cooperate in science and business, communicating in at least one foreign language. The aim of the study was to reveal students' attitudes to foreign language learning at Lithuanian University of Health Sciences (LUHS), Kaunas University of Technology (KTU), and Aleksandras Stulginskis University (ASU). The objectives of the study were to discuss the theoretical aspects of foreign language learning and to reveal the students' attitude towards the process of foreign language learning: the teachers' competence; the climate of studies and the application of the elements of problembased learning. The following methods were applied in the study: analysis of scientific literature and a questionnaire survey. The results of the study showed that most students thought that their foreign language competence was sufficient, while the teachers' competence was seen as deficient. The main problems about the climate of studies that the respondents indicated were inconvenient schedules and insufficiently interesting studies. Meanwhile, the students' opinion about the application of the elements of problem-based learning in foreign language studies was favourable.

Keywords: climate of studies, foreign language teaching, problem-based learning, students' and teachers' competence. 


\section{Introduction}

Studies at a higher educational institution prepare students for transferring their experience into a wider context of values and social phenomena, and, therefore, the study programme should allow a student to delve into the sphere of various social interests, which can be revealed through various studied subjects. To achieve an effective solution, the study programs should include fundamental and applied subjects, as well as the fields of humanities, natural sciences, social sciences, etc. (Kraujutaitytè, 1998). According to Barnett, any attempts at limiting the studies of these subjects are potentially aimed at forming a less open society (1990). The best study programmes in engineering, medicine, education science, and other fields of higher education are multi-disciplinary, integrating theory and practical activity, promoting independent learning and problem-solving, stimulating the students to formulate and highlight the reasons for their actions, creating conditions for the students' work in groups, and involving them into activity through which socially important moral and competence-related issues are tackled (Barnett, 1990).

Continuous updating of specialist knowledge, access to the most recent literature in foreign languages, possibilities for participation in various international conferences and joint projects with foreign partners, and the associated need for foreign languages highlight the relevance of the education and training of specialists who would not limit their activity to work in a concrete sphere, but rather - on the basis of the concept of life-long learning - would be able to cooperate in science and business, communicating in at least one foreign language.

The aim of the study was to reveal students' attitudes to foreign language learning at Lithuanian University of Health Sciences (LUHS), Kaunas University of Technology (KTU), and Aleksandras Stulginskis University (ASU).

\section{Objectives:}

To discuss the theoretical aspects of foreign language learning.

To reveal the students' attitude towards the process of foreign language learning and teaching: the teachers' competence; the climate of studies and the application of the elements of problem-based learning.

Methods of the study: analysis of scientific literature and a questionnaire survey, using closed-type questions. The study included 303 students who were learning foreign languages at Lithuanian University of Health Sciences (LUHS), Kaunas University of Technology (KTU), and Aleksandras Stulginskis University (ASU).

\section{The Main Theoretical Principles Were the Following}

Students' empowerment for studies was analysed on the bass of the principle of the individualization of the module-based teaching theory, following which, according to Jucevičiene (1989), in view of the transition from elitist higher education to mass higher education, studies should be individualized with respect to each learner's needs and potential possibilities.

According to Ramsden (1995), studies at a higher educational institution are not a quantitative accumulation of facts or knowledge about processes, but rather 
a change in ways we perceive the world. If the result of learning is the acquisition of knowledge, which - according to Jovaiša (1993) - manifests itself through the ability to act differently, then, consequently, according to Lipinskienè (2001), quality learning at a higher educational institution is a qualitative change of the learner's activity through the improvement of the ways the student understands the world. All this process depends on the student's attitude to learning.

In many universities, the problem-based learning system is a relatively new direction in didactics (Carrera, 2003), corresponding to the aims of the modern medical education (Woods, 1994). The introduction of problem-based learning (PBL) into the traditional system of studies results in a new quality of studies as well as a special culture of teaching and learning. The co-existence of the traditional and the modern features of the system of studies creates a specific academic environment at a university, and therefore the preservation of the traditional and the modern is becoming one of the main objectives of the progression system of studies, allowing for the prognostication of changes in the culture of teaching and learning (Šveikauskas, 2008).

\section{Theoretical Aspects of Foreign Language Learning}

Upon entering a higher educational institution, a student starts studying certain subjects which require competence in a specific field, called the subject-specific competence. When entering foreign language studies, students "bring" with them certain foreign language competence, which is clearly defined in the Lithuanian general education programmes and national general education standards (Lietuvos bendrojo lavinimo mokyklos bendrosios programos ir bendrojo išsilavinimo standartai, 2009).

An excellent study defining the communicative competence of a foreign language learner was conducted by Canale and Swain (1980). In their definitions, the structure of communicative competence consists of four different components: 1) grammatical competence, which includes morphology rules, syntax, semantics, and phonology; 2) discourse competence, which in many aspects is an addition to the grammatical competence. This is the ability to link sentences when speaking, or simply driving the conversation into a significant whole; this includes everything from a simple conversation to a long written text. While the grammatical competence focuses on the sentence-level grammar, the discourse competence deals with relationships between sentences; 3) sociolinguistic competence is competence that analyses the variation in language elements and the differentiation of the language under the influence of social and linguistic factors; 4) strategic competence is verbal and non-verbal communication strategy that can be used for the compensation of various issues arising in communication due to insufficient knowledge of a foreign language, maintaining the conversation through repetition, indirect phrasing, or hesitation sounds.

However, Van Eko (1986) complemented this classification and identified the following competences: 1) linguistic competence, i.e. learning the vocabulary and certain structural rules, ensuring language coherence; 2) sociolinguistic competence, i.e. "the ability to use and interpret language forms with situational appropriacy" (Sheils, 1995); 3) discourse competence, i.e. the ability to understand 
coherent and clear phrases when communicating; 4) strategic competence, i.e. the ability to use verbal and non-verbal strategies to compensate the speaker's lack of adequate knowledge of the language; 5) socio-cultural competence, i.e. a certain degree of familiarity with the socio-cultural context in which the language is used; 6) social competence, i.e. willingness to communicate and self-confidence when communicating with others, knowing the rules of conduct, and the ability to behave appropriately in social situations.

The Common European Framework of Reference (CEFR) for Languages lists three main components of communicative competence: language competence (the ability to use language resources to form well-structured messages), sociolinguistic competence (possession of knowledge and skills for appropriate language use in a social context), and pragmatic competence (functional uses of linguistic resources using scenarios or predetermined scripts of interactional exchanges) (Council of Europe, 2001, p. 13).

Thus, these competences of foreign language learning show that language learning is more than a mere acquisition of knowledge. It is not simple memorizing words or grammar structures, mechanical training in pronunciation, or compulsory reading of texts using a dictionary, but rather a very tight relationship between the conscious and the unconscious, between the internal and the external language i.e. this is thinking in one or another foreign language.

Students' ability to work independently is also a highly important skill when learning foreign languages. Birkenbihl (2001) stated that when teaching foreign languages at a higher education institution, no extremes are acceptable on the scale of teaching-learning styles. The learner should choose what and how to learn, depending on the stage of learning and the specific abilities to be developed. The learner's success depends not on the selection of the learning style, but rather on the use of this style. The learner's independence manifests itself though his or her ability to identify a concrete need for language knowledge, and to use the available learning options appropriately - be they exercises in class, individual consultations with the teacher, or work with literature or technical instruments. According to the author, independent students are capable of self-evaluation and appropriate selection of the learning style.

Obviously, a significant responsibility when organizing students' independent work falls on the teacher and the higher educational institution, as they have to provide the following learning resources: the library (dictionaries, specialty literature, audio and video records, etc.); computer classes; and the teacher's competence.

Students should assume greater responsibility for their learning, they should communicate and cooperate with each other and their teachers concerning the selection of tasks and their execution; they should also search for the best skillforming and knowledge-developing techniques. This would empower students for more efficient foreign language learning.

According to Lipinskienè (2001), a teacher's competence consists of the subjectspecific, scientific, pedagogical, and communicative competences. The subjectspecific competence of a foreign language teacher at a higher education institution is based on the exhaustive knowledge of the taught subject. A teacher's successful 
work is hardly possible without basic skills. Language teaching at a higher education institution requires deep knowledge in the ongoing changes, and searching for new information because live foreign languages continuously develop, many new words and expressions emerge, and the application of grammar rules changes as well. If the teacher is not improving his or her subject-specific competence, his or her skills become useless. For a teacher of foreign languages, the most effective competence improvement is achieved through periodic refresher courses in the target language speaking countries, and training at higher education institutions where the subject is taught for specific purposes (e.g. for students of technical specialties) (Zujienè, 1991).

Scientific activity of a foreign language teacher is essentially similar to that of teachers of any other specialties. Like others, teachers of foreign languages create, apply, and disseminate new knowledge, and conduct various studies. According to Tijūnèlienè (1998), a teacher-researcher requires broad education, erudition, willingness to develop and to seek novelties, a critical approach to scientific literature, delving into the essence of the taught subject, and familiarization of the students with the results of his/her research.

One of the major components of a teacher's pedagogical competence is knowledge of the didactics - i.e. familiarity with the didactic systems, and application of modern teaching and evaluation methods and techniques. A foreign language teacher has to know psychology and educational management. He or she should be able to organize the pedagogical process, making the maximum use of knowledge in management, planning, organization, control, etc., because foreign languages are among more difficult subjects, which require the use of more numerous and more variable teaching and learning techniques to ensure better acquisition of knowledge.

The communicative competence of a foreign language teacher at a higher education institution should also include communication, group work skills, knowledge of foreign languages, and abilities and skills in computer work. Thus, a teacher is not seen merely as a source of knowledge. With certain knowledge, foreign language skills, experience in the culture of a foreign language-speaking community, responsiveness to students' needs and interests, and understanding of the language learning process, a foreign language teacher becomes a task manager in the classroom, a students' advisor, a participant of the learning process, a guarantor of communication feedback, a competent companion in a conversation in a foreign language, an attentive listener, an observer, a researcher, and a patient person. Birkenbihl (2001) stated that an increasing number of foreign language learners understand that their past failures were not a result of the lack of their mental capacity. Understanding this does not only facilitate foreign language learning, but also increases self-confidence.

The application of active methods of learning helps to create and maintain a successful learning environment because the student becomes the subject of teaching, which in turn gradually closes the gap between willingness and necessity to learn. Ellis and Beattie (1986) stated that a teacher of a foreign language should be capable of creatively applying the following active learning methods during the classes: modelling and analysis of problematic situations, discussion, conference, 
debate, role-playing game (when a person imagines that he or she is someone else in an imaginary situation, and consciously copies that someone else's behaviour and attitude), improvisation (a situation created and acted out using one's ideas), representation (a close look at one peculiar moment of a selected topic), and a theatrical forum (simulation of a conflict situation between group members, while others act as the audience; both the actors and the audience may stop the action and ask for advice, ask questions, or propose possible solutions).

When discussing, debating, role playing, improvising, and presenting the world of their characters during theatrical forums, students relax their feelings, emotions, free their imagination, and forget that they are actually speaking in a foreign language. The application of these methods forms the student-teacher relationship that, using W. von Humboldt's definition, could be called parity-based - i.e. the teacher and the student are working together as equal partners. As a result, students become more self-confident, more readily expressing their opinions in a foreign language - and this, in turn, stimulates thinking. Thus, by using these methods, the teacher helps his/her students to achieve better fluency in foreign language use, and also stimulates them to think in a foreign language. However, despite these advantages, these methods are not the only or the main teaching techniques because their applicability depends on the students' level of language knowledge.

Klimovienè (1998) stated that the application of various research methods in the teaching/learning process stimulates creative cooperation rather than competition. Such relationships result in mutual trust and honesty, help to overcome emotional stress and anxiety, thus promoting self-confidence, and improve foreign language skills in all four fields of linguistic activity - listening, speaking, reading, and writing.

Problem-based learning (PBL) is widely applied in medical studies, but can also be used in learning foreign languages. Three major principles make PBL distinct from traditional learning: 1) the problem works as a stimulus for learning; 2) this is an educational technique rather than an isolated instructing method; and 3) this is a student-oriented technique (Kilroy, 2004). Problem-based learning is a specific method consisting of numerous individual components that students encounter when working in small groups and analysing the selected problems. Students' learning is significantly influenced by the following criteria: active processing of information, activation of previously acquired knowledge, relevant contents, and possibilities for knowledge organization and improvement.

Problem-based learning as a system is more conducive to the development of a student's personality, compared to the traditional teacher-oriented teaching which is to a greater or lesser extent dependent on the contents of the lecture and the attitude of the teacher (Šveikauskas, 2005; Beachey, 2007). The problem-based learning system helps the teacher to understand his or her students better because through discussions, the teacher motivates all students to express their opinion, and improves the contents of the studies, taking into account the students' needs (Barman, 2007).

The principal idea of problem-based learning is that the problem to be solved is the stimulus for learning. This is not simply a possibility to solve problems - rather, this is a possibility to learn, problem solving being merely an impulse for learning. 
PBL is an integrated type of learning based on the interaction between the student and the teacher (the tutor), characterized by a systematic independent cognitive activity - i.e. the acquisition of new knowledge and modes of action through solving practical problems. Thus, trying to tell students where they are wrong and where they are right may result in a clash of opinions. In such situation, the traditional approach to the development of students' skills becomes controversial with respect to the meta-cognition model whose aim is to stimulate students' thinking and to motivate them for acquiring learning management skills. Students have to learn to express their thoughts comprehensively and non-impulsively so that consideration, thinking, and detailed explanation become a habit. The character of the clash of opinions may depend upon the teacher's educational competence and the students' ability to learn independently (Šveikauskas, 2005).

The adequacy of the workload and the flexibility of the contents become highly important when empowering students for successful studies. A teacher of foreign languages should monitor if the workload matches the students' possibilities. Ramsden (1995) stated that excessive content volume is the mistake that is made most easily when compiling curricula. Efforts should be made to minimize this volume, yet ensuring that students learn this smaller volume impeccably. Excessive workload and strain make students apply minimization strategies, and as a result, they graduate with scattered, unclear knowledge about the "covered" topics. Not only does excessive load impede working efficiency, but it also damages the quality of teaching. For this reason, certain problems arising in the studying process should prompt the teacher to alter the contents of the module, taking into account the students' needs. The contents of the module should be continuously reviewed and complemented with new scientific data and various novelties.

When empowering students for successful studies, it is highly important to provide students with really valuable information about their work. This peculiarity is related to the teachers' accessibility to students. Among all the features of good teaching that students see as important, feedback (information about the work that is being evaluated) ranks among the most frequently mentioned ones. Thus, the discussion on efficient teaching and evaluation should necessarily include the analysis of the effect of feedback on students' progress.

Ramsden (1995) stated that feedback use conceptualizes the relationships between students and teachers as a single interaction or a dialogue rather than a unidirectional communication. The teacher shows that he or she is interested in what the student is saying, searches for arguments, tries to explain various things to the student, or tries to persuade the student to look at the issue from another aspect. Care should be taken to ensure that negative comments are counterbalanced by the positive ones, and the teacher's behaviour should be subtle in order to ensure that critical feedback is really helpful to the students. Learning to find the appropriate tone and level of concreteness of the feedback is one of the most complicated fields of the art of teaching, yet it should be mastered in order to achieve high-quality teaching (Ramsden, 1995).

Evaluation as continuous feedback on the results of the activity plays an especially important role in language teaching. The modern approach of the education science emphasizes the individual, and thus the evaluation system that helps the learner 
participate in the evaluation process and assume responsibility for his/her own results meets modern-day requirements.

The individual cumulative index (ICI) is an element of module-based teaching. According to Jucevičienè (1989), certain differences from the traditional didactic system emerge within the module-based teaching system; these differences stimulate students' active participation in the process of studies, help to individualize studies and select the learning pace that is more suitable for the students, and create conditions for continuous high-quality control. These principles are especially suitable in language studies because here a relative margin of learning can be set i.e. the learning outcomes can be clearly defined.

Certain positive and negative aspects of the ICI evaluation technique may be seen in language teaching. Brunevičiūtè (2000) indicated that the application of the ICI evaluation system increases the students' responsibility and the possibility of choice, at the same time minimizing the subjectivity of the evaluation and the probability of a stressful situation, increasing mutual trust between teachers and students, and highlighting the trend of a more consistent distribution of the evaluation results.

Several shortcomings of this evaluation system may also be identified, the students' attitude being one of them. If the ICI system is not sufficiently clearly explained to the students at the beginning of the study course, students sometimes fail to see the significance of daily evaluation, and hope to get good evaluations if they prepare well for the intermediate and the final control examinations. Sometimes teachers also fail to follow the system they present to the students. Finally, this system is more oriented towards weaker and mediocre students, providing them with a possibility to earn a certain portion of the score through class participation alone, thus partially compensating for poorer preparation for intermediate and final examinations. To a certain extent, this system places more capable students at a disadvantage. When applied for the evaluation of language learning, the ICI technique is sufficiently reliable, helps to solve some issues in evaluation, and increases students' responsibility as well as objectivity of the evaluation.

In general, the development of students' multi-component communicative competence in a foreign language at a higher education institution places certain requirements both for the students and for the teachers. Students have to learn to work independently and should assume significant responsibility for their learning. Teachers are involved in the organization of student's learning process, and thus not only do they have to continuously update their knowledge of the subject and their foreign language skills, and to participate in research activity, but they should also select and apply suitable teaching and learning methods, consult their students, and work as task managers. In other words, teachers should have subject-specific, research, and pedagogical competence.

Concerning teaching/learning methods, student-oriented active methods are preferable - including problem-based learning. The application of such methods increases students' independent learning skills, stimulates student-student and student-teacher cooperation, and helps to create a climate of studies that is conducive to learning. Generalizing the conditions for foreign language studies at a higher educational institution, an important point is that students entering the institution should have sufficient competence in the foreign language. 


\section{Students' Attitude to the Process of Foreign Language Learning and Teaching}

Each higher education institution in Lithuania is trying to improve the process of studies in order to ensure that their graduates are capable of adapting to the changing economic, political, cultural, educational, technological, and other conditions. In the process of the reformation of specialist education and training, Kaunas University of Technology started teaching business and information technologies in English alongside the standard courses of English, German, French, and Russian, while Lithuanian University of Health Sciences introduced a novel educational system problem-based learning - in 2007.

This study was aimed at identifying the students' predominant attitude towards the process of foreign language learning and included 303 students from LUHS, KTU, and ASU. The respondents were selected by applying a non-probability sampling.

The questionnaire of the study consisted of 61 questions that allowed the respondents to express their opinions. The logic of the question sequence was based on the principles of creation of an effective educational environment (Jucevičienè, et al. 2010; Kirikova, et al. 2008). The responses to closed-type questions were presented by marking specific positions on the Likert-type scale ("Strongly agree", "Agree somewhat", "Disagree somewhat", and "Uncertain").

Results of the study. The subjects' age varied, but the majority of them were third-year students (71\%) (see Fig. 1). Concerning the subjects' distribution by sex, $75.9 \%$ were females, and only $24.1 \%$ - males.

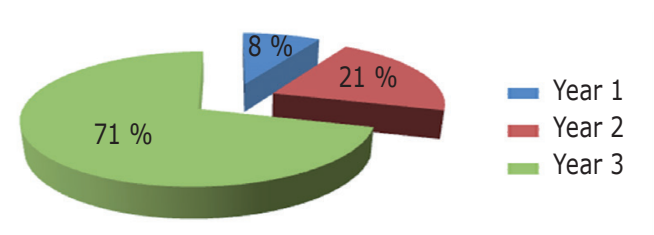

Fig. 1. Number of students by year of studies

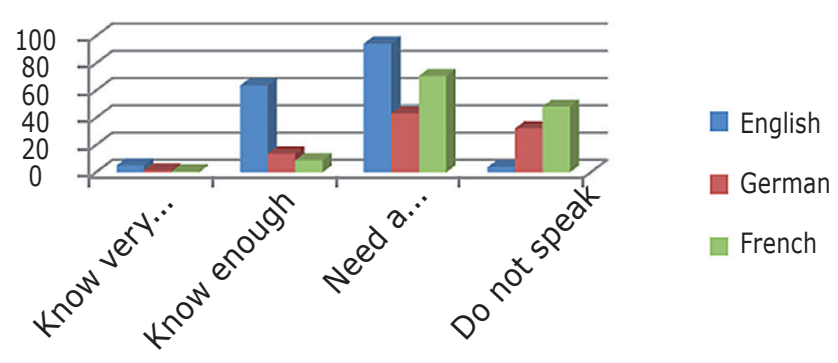

Fig. 2. Students' knowledge of foreign languages

The findings of the study showed that $63.8 \%$ of the students could speak English, $13.8 \%$ - German, and 8.9\% - French. Also, as shown in Fig. 2, 70.7\% of the respondents could read professional literature in 2 foreign languages, and $43.1 \%$ of the students in 3 foreign languages. There are three principal foreign languages taught in Lithuanian 
secondary schools - English, German, and French. Schoolchildren also choose a second foreign language to learn after the first four grades. Schoolchildren's knowledge of the languages they learn is evaluated and reflected in their school graduation certificates. In addition to that, self-reported knowledge of a foreign language ("know very well", "know enough", "need a dictionary" and "do not speak") was evaluated.

As the teacher's competence has a significant influence on the process of foreign language learning, twelve questions were formulated to identify the students' opinion about teachers' competence. The results of the study showed (see Fig. 3 ) that the majority of the respondents (82.6\%) thought that the acquired knowledge will be useful in the future (an indirect reflection of the teachers' subject-specific competence), and $56.8 \%$ of the students thought that their teachers evaluated students' experience and competence, and provided information about learning possibilities.

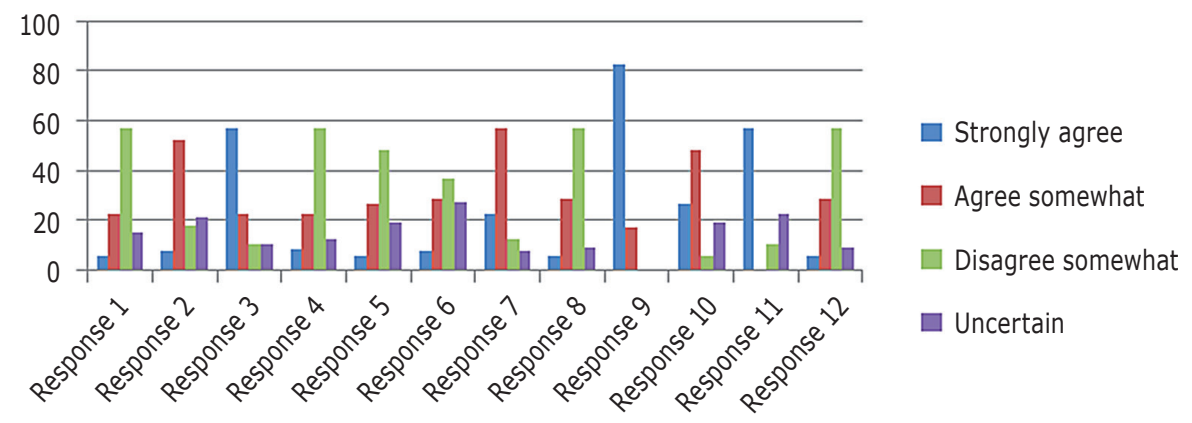

Response 1: The provided information is related to other topics of the module

Response 2: The provided material is modern and up-to date

Response 3: The teacher evaluates students' experience and competence

Response 4: The teacher evaluates students' needs

Response 5: The teacher complements the taught material if necessary

Response 6: The teacher encourages students to be active, to discuss, and to ask questions during the class

Response 7: The pace of the studies corresponds with the students' language learning needs

Response 8: The objectives set for achieving the aim are clear

Response 9: The acquired knowledge will be needed and useful in the future

Response 10: All the necessary information about what and how one should learn is provided

Response 11: Information about learning possibilities is provided

Response 12: Various active learning methods are applied, including lectures, discussion, group work, brainstorming, etc.

\section{Fig. 3. Students' opinion about teachers' competence}

However, only a few students strongly agreed that the acquired information was related to other topics of the module $(5.6 \%)$, that the provided material was upto-date and modern in character $(7.6 \%)$, that the objectives set for achieving the aim were clear (5.6\%), and that various methods were applied, including lectures, discussion, group work, brainstorming, etc. (5.6\%).

The climate of the studies was addressed in questions on students' relationships, parity-based activity of students and teachers, mutual trust, direct and open 
communication, and the possibility to learn from each other's mistakes. Responses to these questions are presented in Fig. 4. The majority of the respondents $(86.6 \%)$ thought that they had a possibility for continuous and timely access to the evaluation of their results. Also, $72.6 \%$ of the students positively evaluated their relationships with the academic group. However, many students (56.8\%) complained about inconvenient schedules and uninteresting studies. One-third of the respondents thought that their relationships with the teachers were not parity-based $(36.5 \%)$, and nearly one-half $(48.3 \%)$ of them thought that they were not provided any possibilities for creative work.

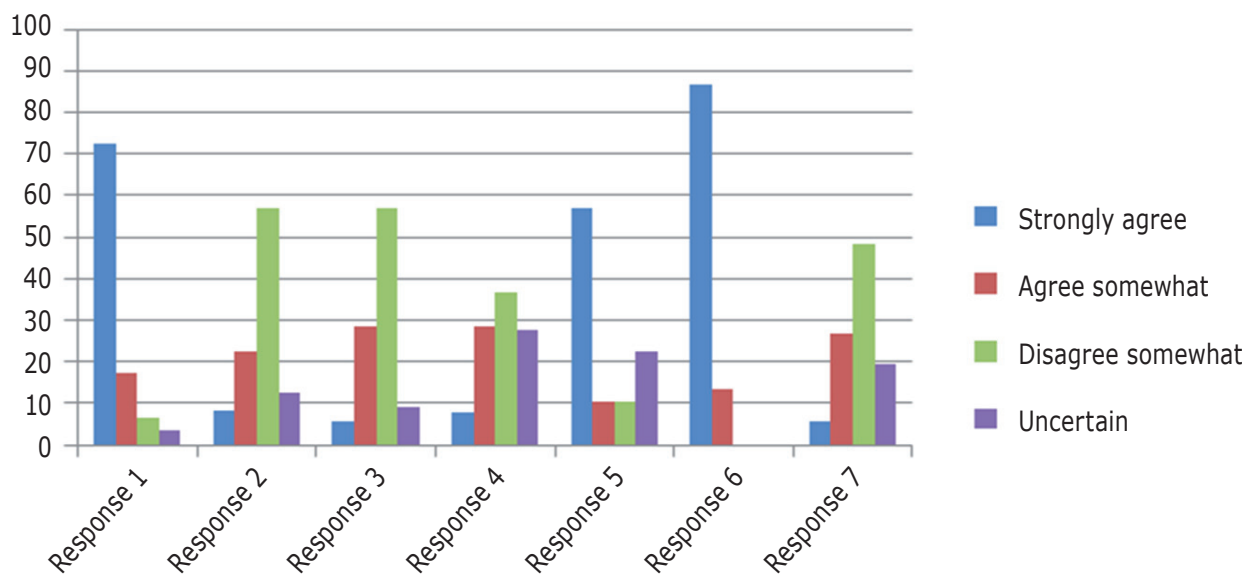

Response 1: Pleasant relationships with the academic group

Response 2: Convenient time of studies

Response 3: Interesting studies

Response 4: Parity-based relationships with the teacher(s)

Response 5: Behaviour and knowledge rather than the person are evaluated

Response 6: There is a possibility for continuous and timely access to the evaluation of one's results

Response 7: The possibility for creative work is provided

\section{Fig. 4. Students' opinion about the climate of studies}

To identify the students' opinion about the implementation of the problem-based learning system in the studies of foreign languages, the respondents were given 9 more questions. The results of the study showed (see Fig. 5) that the majority of the respondents (91.8\%) would like to try something new, and a greater part of the students would like to learn languages through drawing charts and mind maps $(76.6 \%)$, discussing subject-related issues (74.8\%), seeking answers to questions $(62.4 \%)$, and analysing the emerging problems (56.8\%). However, only a small part of the respondents (7.6\%) indicated that they would like to learn foreign languages through searching for information with the help of new technologies. 


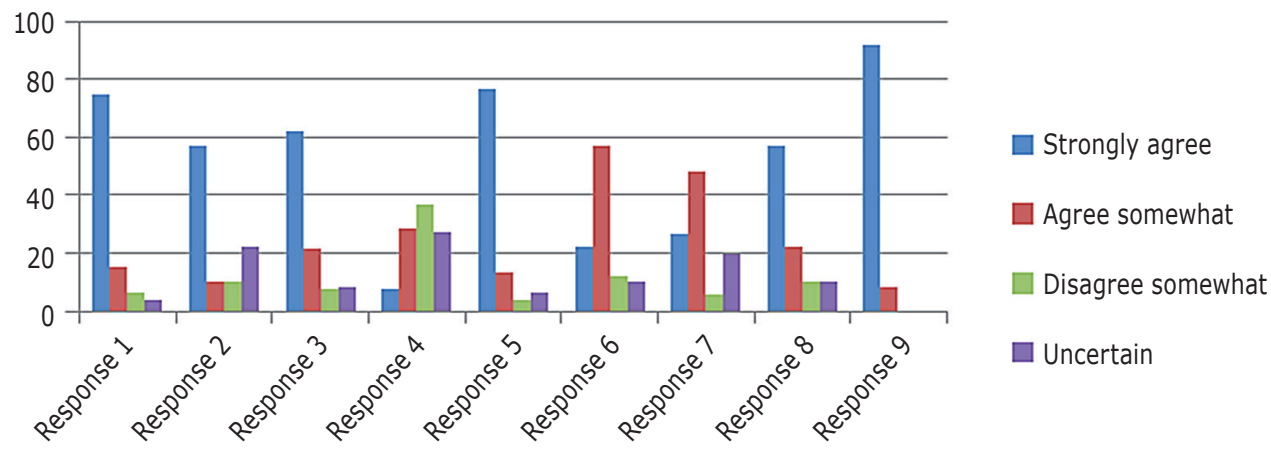

Response 1: When discussing interesting medical situations

Response 2: When analysing a problem

Response 3: When searching for answers to questions

Response 4: When searching for information using modern technologies

Response 5: When drawing charts or mind maps

Response 6: When independently setting one's learning objectives

Response 7: When independently evaluating the work of one's group

Response 8: When associating the new information with the already acquired knowledge

Response 9: I would gladly try something new In LUHS only

Fig. 5. Students' opinion about the implementation of the problem-based learning system in foreign language studies

Summing up, it can be stated that the students emphasized many positive aspects of effective environment for foreign language learning. According to Lipinskienè, "students' empowerment for studies is the creation of the educational environment whose conditions provide each student with the power to learn, and contribute to the success of the studies" (Jucevičienè, et al. 2010, p. 212). Seeking to create such an environment in his or her classes a teacher tries to create parity-based climate, helps the students to internalize their system of knowledge and develop understanding, coordinates with the students the aims and the contents of studies as well as the methods of evaluation, and also helps to select suitable learning aids and to assimilate the learning contents on the basis of the deep rather than the superficial approach. In such an environment, the autonomy and responsibility for the results of their studies allow the students to control their own learning process, and tolerance of failures, reflection, self-control, and self-evaluation help them learn from their mistakes, increase their self-confidence, and maintain motivation for high-quality learning and the deep approach to learning. 


\section{Conclusions}

Studies of foreign languages develop linguistic, sociolinguistic, discourse, strategic, socio-cultural, and social competences.

Teachers of foreign languages should have appropriate subject-specific, scientific, communicative, and pedagogical competence; a special emphasis here falls on the application of various foreign language teaching and learning techniques which help students to learn more successfully and efficiently.

The generalized results of the study showed that the students of LUHS, KTU, and ASU had good knowledge of foreign languages. The majority of the students spoke one foreign language, and could read professional literature in two foreign languages.

The study showed that, according to the students, the teachers' competence was insufficient. The teachers evaluated their students' experience and competence, and provided information about learning possibilities. However, they did not relate the provided information with other topics of the module, the provided material was not recent, and the teachers did not apply such methods as discussions, group work, or brainstorming.

The evaluation of the climate of the studies showed that the students had a possibility for continuous and timely access to the evaluation of their results, yet the schedules of studies were inconvenient, and the studies were not interesting.

The students' opinion about the application of the elements of the problem-based learning technique in foreign language studies was favourable. The students were willing to try something new, and would like to learn foreign languages through drawing schemes and mind maps, discussing subject-related issues, seeking answers to questions, and analysing the arising problems.

\section{References}

Barman, A., Jaafar, R., \& Rahim, A. F. (2007). Perception of tutors about the problem-based learning sessions conducted for medical and dental schools' students of University Sains Malaysia. International Medical Journal, 14 (4), 261-264.

Barnett, R. (1990). The Idea of Higher Education. Buckingham: SRHE and Open University Press.

Beachey, W. D. (2007). A comparison of problem-based learning and traditional curricula in baccalaureate respiratory therapy education. Respiratory care, 52 (11), 1497-1506.

Birkenbihl, V. F. (2001). Lengviau mokykimès užsienio kalbu. Vilnius: Alma Littera.

Brunevičiūtè, R. (2000). Vertinimo sistema taikant IKI metoda diegimas KMU Kalbu katedroje // Aukštojo mokslo sistemos ir didaktika: Konf. medžiaga, Kaunas.

Canale, H., \& Swain, M. (1980). Principles and Practice in Second Language Learning. Oxford.

Carrera, LI, Tellez, TE, \& D'Ottavio, A. E. (2003). Implementing a problem-based learning curriculum in an Argentinean medical school: implications for developing countries. Acad med, 78, 798-801.

Ellis, A., \& Beatlie, G. (1986). The psychology of Language and Communication. New York.

Jovaiša, L. (1993). Pedagogikos terminai. Kaunas: Šviesa.

Jucevičienè, P. (1989). Modulinio mokymo teorija ir praktika. Kaunas: Šviesa. 
Jucevičienè, P., Gudaitytè, D., Karenauskaitè, V., Lipinskienè, D., Stanikūnienè, B., \& Tautkevičienè, G. (2010). Universiteto edukacinè galia: atsakas 21-ojo amžiaus iššūkiams: monografija. Kaunas: Technologija.

Kilroy, D. A. (2004). Problem based learning. Emergency Medicine Journal, 21, 411-413, doi:10.1136/emj.2003.012435.

Klimovienè, G. (1998). Kūrybingumo ugdymas mokant užsienio kalbu // Kalbu studijos aukštojoje mokykloje: Konf. medžiaga, Kaunas.

Kraujutaitytè, L. (1998). Liberalaus aukštojo mokslo koncepcija: kredo ir alternatyvos. Aukštojo mokslo sistemos ir didaktika (konferencijos pranešimu medžiaga). Kaunas: Technologija.

Lipinskienè D. (2001). Studijuoti skatinanti aplinka: jos reikšmè studento mokymuisi. Tiltai, 2, 73-77.

Nakhoul, L. (1993). Letting go: preparing teachers and students for learner in dependence. Oxford: Heinemann Bookfor Teachers.

Ramsden, P. (1995). Learning to Teach in Higher Education. New York: Routledge.

Sheilas, J. (1995). Komunikacija kalbos mokyme. Vilnius: Leidybos centras.

Šveikauskas, V. (2005). Probleminio mokymosi ypatybès studijuojant medicina. Medicina, 41(10), 885-891.

Šveikauskas, V., Kirikova, L., \& Leonas, L. (2008). Peculiarities of changes of roles of students and lecturers in implementation of problem-based learning system // Socialiniai tyrimai: mokslo darbai. Šiauliai: Šiauliu universitetas, 1(11), 85-94.

Van Eko, J. A. (1986). Objectives for Foreign Language Learning. Strasbourg: Council of Europe.

Woods, D. R. (1994). Problem-based Learning: How to Gain the Most from PBL. Waterdown, Ontario.

Zujienè, I. (1992). Užsienio kalbos dėstytojo vaidmuo mokymo procese // Pedagogika, 28, 192-201.

\section{Liudmila Kirikova}

Lietuvos sveikatos mokslu universitetas, Lietuva; liuda.kmu@gmail.com

\section{Irmantas Ramanauskas}

Lietuvos sveikatos mokslu universitetas, Lietuva; irmantasr@gmail.com

\section{Edita Latvelienè}

Lietuvos sveikatos mokslu universitetas, Lietuva; skolopendra2003@yahoo.com

\section{Sigita Stankevičienè}

A. Stulginskio universitetas, Lietuva; sigute.stanke@gmail.com

\section{Dalia Kačergienè}

Kauno technologijos universitetas, Lietuva; amicusverus@gmail.com

\section{UŽSIENIO KALBU MOKYMOSI YPATUMAI LSMU, KTU IR ASU: STUDENTU POŽIŪRIS}

Santrauka. Didejanti mokslo reikšmè, sparčiai augantis informacijos srautas bei užmegzti nauji dalykiniai ir kultūriniai ryšiai su užsienio šalimis - tai tik keli veiksniai, salygojantys gero specialisto rengima, kurio viena iš svarbiausiu daliu yra praktinis gebéjimas komunikuoti keliomis užsienio kalbomis. Ivertinant pastovu specialybiniu žiniu atsinaujinima bei atsivèrusias galimybes skaityti naujausia literatüra užsienio kalba, dalyvauti užsienyje organizuojamose konferencijose, ivairiuose projektuose su užsienio partneriais ir su tuo susijusi užsienio kalbu poreiki, tampa aktualu parengti specialistus, kuriu veikla neapsiribotu vien tik konkrečia darbo veikla, bet, remiantis mokymosi visa gyvenimą samprata, jie galètu bendradarbiauti mokslinèje ir dalykinèje veikloje laisvai komunikuodami bent viena užsienio kalba. Tyrimo tikslas - atskleisti 
studentu požiūri i užsienio kalbos mokymąsi LSMU, KTU ir ASU. Tyrimo uždaviniai: aptarti teorinius užsienio kalbu mokymosi aspektus ir atskleisti studentu požiūri i uźsienio kalbu mokymo ir mokymosi procesa: dėstytojo kompetencija, studiju klimata ir probleminio mokymosi metodo elementu taikyma. Darbe taikomi tyrimo metodai: mokslinès literatūros analizè, anketinè apklausa. Tyrimo rezultatai parodè, kad dauguma studentu savo užsienio kalbos kompetencija nurodo esant pakankama, tačiau dėstytoju kompetenciją jie vertina kaip nepakankama. Studentai teigiamai vertino probleminio mokymosi metodo elementu naudojimą mokantis užsienio kalbu.

Pagrindinès sąvokos: probleminio mokymosi metodas, studento ir dèstytojo kompetencija, studiju klimatas, užsienio kalbos mokymas(is). 